\title{
Being an English academic: a social domains account
}

\begin{abstract}
This paper considers the differential placements of social actors in the contemporary English university, as practices consistent with neoliberal ideologies become increasingly influential. It uses Layder's theory of 'social domains' - which links the day-to-day experiences of individuals with the possession and distribution of cultural and material resources throughout the social system - to demonstrate how one emerging outcome of the neoliberal 'turn' in higher education is the gradual change in the agential location of various kinds of participants in it. While the meanings of categories such as 'student' or 'academic' have never been immutable, these meanings are currently changing in ways that are irreducible to the intentions of the individuals who previously or currently occupy these roles. Using the first-hand experiences of the author, the paper explores how the options available change in relation to alterations in the structured social relations among students, those on precarious conditions of employment, and those occupying more influential roles in the institution. Examples are provided of interventions by people opposed to both the rhetoric and the reality of developments in the sector, and the reasons for their limited effectiveness are also discussed.
\end{abstract}

\section{Introduction}

While I was writing this paper, evidence to the UK House of Lords Economic Affairs Committee was given by the Chancellor, Philip Hammond, that included plans to interrogate 'the information we provide to [university] students to enable them to make value-for-money assessments about what they are buying and what it's going to cost them' (V. Ryan, 2017). The same article quotes a Whitehall source as wanting to protect students from courses 'that are a waste of money because there is no earnings uplift'. In his speech to the Universities UK annual conference in September 2017, the then Universities Minister, Jo Johnson, indicated that he intended to introduce contracts between universities and students that would require 'full compliance with consumer law'1. Such representations of educational experiences as the private purchase of consumer goods are consistent with a trend that has gained increasing traction, in the UK and elsewhere, since the 1970s. It is a trend that has not gone unobserved, and has met with considerable resistance, with numerous critics pointing out what one summarises as the 'grimly utilitarian' nature of the 'world we are bequeathing to future undergraduates' (Coman, 2017). Two other, related trends are apparent at the time of writing. The economic costs of attending universities in England have made them the most expensive in the world (Walker, 2015), with increases not only in fees and interest on the loans used to pay them, but also rising costs of accommodation and maintenance. And, at just the same time as government ministers plan to turn the screws ever tighter on universities' accountability, evidence is being shared of a crisis in the mental health of both

\footnotetext{
${ }^{1}$ https://www.gov.uk/government/speeches/jo-johnson-speech-to-uuk-annualconference
} 
staff $^{2}$ and students in English universities, with sharp increases in self-harm, referrals for counselling and even suicides (Marsh, 2017) ${ }^{3}$.

These may all be seen as examples of broader social changes, not confined to this country, that include 'the slow collapse of public health and education, resurgent child poverty, the epidemic of loneliness, the collapse of ecosystems', which 'have all been either catalysed or exacerbated by the same coherent philosophy' neoliberalism (Monbiot, 2016). Space permits neither a detailed discussion nor a review of the extensive commentaries and critiques of this concept, and other authors in this special issue provide further examples of both. Instead, I begin by suggesting that it is helpful to appreciate the ways in which powerful, dominant forces interact with local, immediate experiences, and in order to do so (again mindful of the constraints of space) I draw on the theory of social domains developed by Derek Layder (Layder, 1997). All of us experience much of our lives in the domain that Layder identifies as 'situated activity'; that is, 'face-toface conduct' involving 'the presence of particular people at specific times and places' (Layder, 1997: 85). As employees, we are subject to the characteristics of the institutions where we work, which may be understood as examples of the domain of 'social settings', defined as 'local holding points for aggregations of reproduced relations and practices' (Layder, 1997: 114). Most remote from our direct experience is the domain of 'contextual resources', which focuses on 'power and domination and the discourses and practices that undergird various forms of hierarchy and inequality on a society-wide basis' (Layder, 1997: 4). At the same time, each individual has their own 'psychobiography'. This domain recognises 'the self as a historical emergent', with 'important unique configurations of experience' (ibid.: 47).

My contribution to this special issue, influenced by my own psychobiography, explores how my personal experiences interact with the broader political changes under review. In drawing on the analytical tool of these four social domains, my aim is to illustrate the interrelationships between changing structured social relations within universities, the much wider political context for these, whose antecedents stretch back to long before I was born, and my experience as an academic, the material I have sought to teach, and the immediate contexts in which I have found myself doing so. It is important to emphasise that, as Layder $(1997: 77,114)$ makes clear, the domains are 'completely interdependent' and the effects and influences that they have on each other 'are diffuse, overlapping and interpenetrating'. Indeed, as indicated in the final section of this paper, recent developments in social theory increasingly recognise the profound interconnectedness not only of people and social institutions but also of the material and biological world, thus thoroughly undermining the individualism on which neoliberalism rests.

\section{Some background - personal and political}

In the 1980s, before taking up an academic post, I experienced the impact of Conservative party policies on education in my role as an 'advisory teacher' of

\footnotetext{
2 http://wonkhe.com/blogs/the-rise-of-academic-ill-health/

${ }^{3}$ http://www.bbc.co.uk/news/education-41148704
} 
English. This entailed reducing the negotiated, context-specific support that had been provided by the local education authority for schools and teachers, and instead 'training' them in the implementation of the new 'National Curriculum'. As one of the 'core' subjects, English - and particularly English language - was in the political spotlight, 'subject to more official inquiries, reports and personal ministerial interest than any other school subject' (Stubbs, 1989: 236). And my subsequent experience working with a project known as LINC - Language in the National Curriculum - recapitulated many of these emerging tensions. The interpretation of their brief by the personnel comprising the LINC team was rejected by the government, which reneged on their undertaking to publish the materials it produced, and imposed a ban on their commercial publication anywhere in the world (see Carter, 1996; Cox, 1995; Sealey, 1994). A number of critical commentaries on this debacle made connections between the English language as a subject of study, on one hand, and pedagogic theory and practice, on the other. That is, should education promote critical reflection, including on ideas about 'standards' and 'correctness', or should it require the unquestioning acceptance of received opinions? A notorious assertion that was broadcast on $\mathrm{BBC}$ radio in 1985, by a Conservative MP, Norman Tebbitt (cited in Carter, 1996: 4), made explicit connections between linguistic and social behaviour:

... We've allowed so many standards to slip. ... Teachers weren't bothering to teach kids to spell and to punctuate properly.... If you allow standards to slip to the stage where good English is no better than bad English, where people turn up filthy ... at school ... all those things tend to cause people to have no standards at all, and once you lose standards then there's no imperative to stay out of crime.

Whereas for hard-line prescriptivists like this, 'bad' language correlates with 'bad' behaviour, the proscribed LINC materials had the potential to illuminate a different sense in which 'power relations are an inherent feature of language' (Goddard, 1991: 38). As Halliday had pointed out:

There is a real sense in which linguistics is threatening; it's uncomfortable, and it's subversive. It's uncomfortable because it strips us of the fortifications that protect and surround some of our deepest prejudices. As long as we keep linguistics at bay we can go on believing what we want to believe about language, both our own and everybody else's.

(Halliday, 1982: 14)

But this was the kind of connection that the government did not want to see encouraged. Prime Minister Thatcher castigated 'hard-left educational authorities and extremist teachers' in a speech to the 1987 Conservative Party Conference, asserting that 'children who need to be able to express themselves in clear English are being taught political slogans' (cited in Ball, 1993: 200). Such unsupported descriptions of teaching practices, widely circulated in print and broadcast media, have been a consistent feature of the discourse on the subject.

While many critics of these developments focused on the substantive aspects of the curriculum, and/or the assumptions about learning underpinning them, some commentators also recognised the more extensive political ambition that 
the 1988 Education Reform Act represented. The strong impetus, on the part of the Conservative government led by Thatcher, for an increase in central state control of education illustrates the paradox of its position, which was to be simultaneously 'opposed to state intervention and the most interventionist government of recent times' (Gamble, 1985: 21). This paradox is explained by the tension between the neo-conservative pursuit of a 'free economy', accompanied by an authoritarian state, and the neoliberal priorities of freedom of choice, the individual, the market and minimal government (e.g. Apple, 1995; Chitty, 1989; Quicke, 1988; Whitty, 1989). The authoritarian strand of the neoconservative education policies of the 1980s is evident in the strict policing of the centralized curriculum, 'so that support for the market, enterprise, and selfhelp [could] be constructed' (Whitty and Menter, 1989: 52), but there were others on the New Right who recognized that 'a rigid program of study could have no place in a market system of schools' (Chitty, 2013: 129). In the decades succeeding the 1990s, under all administrations, a relaxation of control of the curriculum has inevitably accompanied the increasing privatisation of schooling, from City Technology Colleges, to academies and so-called 'free' schools, which are not obliged to follow the national curriculum ${ }^{4}$ (Walford, 2014; West and Bailey, 2013). However, the tension between control (e.g. relentless testing of children throughout their time in school) and 'letting go' persists (Griffiths, 2015), summarised by Holborow (2013: 235) as 'the paradox of free market by government diktat'.

\section{Teacher education as the neoliberal vanguard in the university}

My next job provided me with first-hand experience of another variant on the intersection of politics and education. I worked in a university department of Arts Education, where I specialised in research and teaching about the English Language, on the components of undergraduate degrees that led to a teaching qualification. My experience of this period felt somewhat like being pursued by the architects of the reconfigurations of the (state) school system that I thought I had left behind. Funding for these courses - for in those days, students still received public funding for their studies - was transferred to the Teacher Training Agency (TTA), a body established under the Education Act of 1994 with the aim of establishing a market in teacher training and imposing centralised curricula, always represented (or perhaps 'spun') as 'driving up standards' (Ellis, 2006), 'remov[ing] at one stroke the buffer between government funding and university autonomy' (Pring, 1996: 13). So whereas in other departments on the same campus, students' fees were the responsibility of the Higher Education Funding Council for England (HEFCE), and academics continued to have a fair degree of independence in developing the courses taught, the students I worked with were on a degree programme funded through the TTA, and there were tight prescriptions on the content of their courses. These were stipulated in publications with alliterative titles such as Teaching: High status, high standards (Requirements for Courses of Initial Teacher Training) (Department for Education and Employment, 1998), as well as in subject specific documents such as the Initial Teacher Training Curriculum for Primary English (Department for Education and Employment, 1997). The latter was described by one critic at the

\footnotetext{
${ }^{4}$ https://www.gov.uk/types-of-school
} 
time (Graham, 1997) as 'a most unnecessary document', and the strong feelings it evoked in academics like her are demonstrated in the list of 'key words' she provides for it: 'redundant, repetitive, inapplicable, ill-written, narrow-minded, mean-spirited, atheoretical, partial, unbalanced, unworkable, research-innocent, unimaginative, restrictive and an unwarranted incursion on academic freedom' (p.249). This quotation highlights the focus on the (absence of) intellectual content in the document, on which the author, as a teacher and researcher in the sector, was most qualified to comment. Other critiques at the time drew attention to the wider implications, for research and academic freedom, of 'the trend towards isolating education departments from the rest of higher education' (Deem, 1996: 156), as well as acknowledging the even more farreaching ambition of which these changes were part. Considering the question of why the Thatcher government was relaxing entry qualifications for teachers in the private sector while simultaneously imposing ever more stringent restrictions on university education departments, Barton, Pollard, \& Whitty (1993: 330) suggest that the latter were necessary in order to 'rid the system of the so-called liberal [i.e. progressive] educational establishment'. Again, 'free' market principles were somewhat uncomfortably allied with an authoritarian role for the state. So once again, in the psychobiographical domain, I was experiencing my own position as a university employee in ways that were very much shaped by changes to the social setting: specific configurations of ideas and policies that were explicitly articulated, while changes in the contextual resources that were influencing day-to-day practices were less immediately apparent.

\section{Teaching trainee teachers about English language: a 'social domains' vignette}

At some point in the late 1990s, while still working in this university Education department, I was informed that a course I had taught (courses had been renamed 'modules', reflecting a concept of education as packaged - and marketable - units) was to be reassigned to another member of staff. By now, the Conservative government had lost an election to New Labour, and in 1998 yet another initiative had been imposed on teachers and teacher educators - the National Literacy Strategy (NLS), foreshadowed in the National Literacy Project that had been introduced by the previous government in 1996. This was an extremely tightly prescribed approach to the teaching of reading and writing, and all staff tasked with passing on its requirements to practitioners were issued with a hefty box filled with ready-made slides for the overhead projector (this was the pre-Powerpoint era), together with timed scripts containing the explanatory details that must be communicated.

A textbook that I had found successful in introducing students to language analysis, (Carter, Goddard, Reah, Sanger, \& Bowring, 1997), was struck off the reading list for this module, as was the very useful little guide to 'language myths' (Bauer and Trudgill, 1998), in which various linguists explain the misconceptions inherent in claims such as 'double negatives are illogical' and 'children can't speak or write properly any more'. I was obliged to attend several uncomfortable meetings with more senior staff, where my impulse to explain my rationale for using such texts clashed with their adherence to the imperative of 
'delivering' the prescribed 'training standards'. In terms of the domains identified by Layder, these meetings were examples of situated activity within a specific, and changing, kind of social setting, but I also came to recognise some of the ways in which my own psychobiography contributed to the changing situation in the institution where I was employed.

I was made to feel under pressure to relinquish my commitment to the knowledge and understanding I had acquired through quite extensive study of English applied linguistics, which were aspects of my particular psychobiography. I had by then published my first monograph (Sealey, 1996), which drew on theory and practice about young children's acquisition of metalinguistic understanding, pedagogical ideas influenced by a belief in the emancipatory potential of education, and the functional approach to linguistic description pioneered by Michael Halliday, which had underpinned the LINC project. I had also written about the LINC controversy, including the way it had been distorted in the press (Sealey, 1994), and I had a strong investment in passing on aspects of what I knew in my teaching. In many ways, these experiences were a significant component of my identity, and I was committed to defending them. But as the weight of externally imposed policies bore down on the institution, some of the comfortable personal relationships I had developed with my professional colleagues became strained, and the 'situated activities' of routine interactions began to take on a different character from before, as people responded to the new context in contrasting ways. Several people I had enjoyed working with took up posts elsewhere, and others were absent for prolonged periods with stress-related illness.

All of this was taking place in an increasingly competitive context, as league tables and rankings were being introduced across the public sector, including in schools and universities. Like many other academics, I had by this point come to understand myself as part of a community of scholars, supported by - rather than in competition with - others working in similar fields. This is not to imply that there had been a golden age when universities were devoid of competition; as various commentators have pointed out, scholars have for centuries vied with each other for prestige and reputation (e.g. Collini, 2012; Furedi, 2010). Nevertheless, as a number of academics whose research was in the teaching of literacy were publishing critical commentaries on the NLS and its interpretation by teachers (e.g. Graham, 1998; Hilton, 1998; Sealey, 1999; Wyse, 2003), I thought there was the possibility of a collective opposition to the imposition of these changes to the teaching of literacy, which could prove detrimental to teachers' and children's experiences. However, despite these publications, and some representations from bodies such as CLIE (the Committee for Linguistics in Education), university departments of Education needed to be seen to be compliant and their managers were conscious of how this affected their standing relative to other such departments.

The individuals with whom I found myself in conflict, of course, had their own psychobiographies. The significance of this domain in partially accounting for conflicts like these is that people experience their careers 'from the standpoint of their own idiosyncrasies of personality' as well as 'the specific combination of 
events that attend their passage through the career stages' (Layder, 1997: 48). This department was required to ensure that students (by now reclassified as 'trainees') pass modules covering all the subjects in the primary school curriculum, and the managers to whose projects I was proving an obstruction were not specialists in teaching about language or literacy. Their priorities were shaped by their own areas of academic interest, as well as by their professional achievements, including the attainment of positions as professors and managers in the contemporary configuration of the institution.

In the context of the controversy over how English language should be taught to intending teachers, the more senior staff had a greater investment than I did in the success (as measured in ever more restrictive ways) of the department as a whole, for which they also carried greater responsibility (Hazelkorn, 2008). They dealt more frequently with the continual inspection of our teaching, which was carried out not by the body charged with evaluating other university subjects, the Quality Assurance Agency (QAA), but by the one responsible for inspecting schools, the Office for Standards in Education (OFSTED), with its 'structured, routinized and template-driven process' (Ozga, Baxter, Clarke, Grek, \& Lawn, 2013: 213), whose outcomes carried extreme consequences, as was explained critically at the time in these terms:

The practice of grading initial teacher education courses 1 through 4, besides being suspect in itself ... has resulted in reduced provision of resources, as OFSTED's reports are used to justify the TTA's allocation of student numbers and thus finance to institutions.

(Gilroy, 1999: 217)

The issue of finance turns the analytical perspective to the domain of contextual resources. Sustaining a department of Education within an English university, particularly if that university had a prestigious academic reputation, became increasingly difficult in the 1990s. Not only was there the risk of a decrease in funding following unfavourable inspections by OFSTED, but Education was often perceived as a vulnerable subject in the Research Assessment Exercise (RAE), because of its 'vocational' nature and the way the academic careers of its staff tended to follow periods of classroom-based experience (c.f. Rampton, 1995). Indeed, 'recent and relevant' school experience had become a requirement for teacher educators (Department of Education and Science, 1984), motivated, according to one teacher educator at the time, by the suspicions of the 'New Right' that they were 'manifest incompetents and/or sinister ideologues' (Beattie, 1991: 221). For established academics, this policy of being obliged to return to 'the chalk face' added to the pressure to continue publishing their research (Brown, 1998).

\section{Out of the frying pan?}

The sense of personal liberation I felt when I obtained a post in a School of Linguistics and Applied Language Studies was exhilarating. Although the strictures of the Research Assessment Exercise were still oppressive, I experienced a renewed sense of academic autonomy, able to introduce new modules and pursue research in areas not determined by the narrow definition of the 'unit of assessment' to which I had been confined when working in an 
Education department. Some colleagues in the department I joined, who had not shared my experiences of the reforms imposed on schools and Education departments, were feeling more constraints than they had before, as increasingly more was demanded of them by way of paper trails and legitimisations of their professional judgements (see Shore, 2008 for a discussion of the links between the 'audit culture', subjectivity and neoliberalism). From my psychobiographical perspective, this social setting seemed less restrictive than the one I had left; from theirs, the changes to processes of governance were more striking.

However, having moved institutions several times since leaving the discipline of Education, I had until recently been able to maintain a fairly consistent concept of what a university is and what it is for. In his summary of the history of this particular social setting, Collini (2012: 87) maintains that since the nineteenth and throughout the twentieth century, despite variations, its recognised purposes have consistently included the incarnation of 'a set of "aspirations and ideals" that go beyond any form of economic return'. Like many of the critics of the shift to neo-conservative and neoliberal policies cited above, I have, since experiencing university as a student, held a belief in knowledge, learning and education as intrinsic goods, to which all citizens are entitled. These values are part of not just my psychobiography, but of those of many workers in the education sector. They influence the way teachers, whether in schools or universities, interact with learners in the situated activities of lessons, lectures, seminars and tutorials, even as the social setting of the school or university begins to change around them, and as the contextual resources of funding and governance are reconfigured so as to transform education into a market commodity.

\section{Academic resistance}

There has been extensive commentary on the ruptures in perceptions of higher education on the part of academics, on the one hand, and policy-makers and managers, on the other (although these two constituencies overlap in part, and neither is homogeneous in outlook, of course). Those commentaries, which are not confined to the UK context, are too extensive to summarise here. They appear in (some) news media, in academic journals and there is at least one complete book series, comprising at the time of writing eleven titles, whose aims are 'to foster, encourage, and publish scholarship relating to academia that is troubled by the direction of [the] reforms occurring around the world'. These reforms are glossed as 'changes being inflicted upon universities [that] are being imposed by political and policy elites without any debate or discussion, and little understanding of what is being lost, jettisoned, damaged or destroyed' 5 .

Given the extent of this burgeoning literature, I aim here merely to exemplify some of the themes to be found there, and to relate these to the social domains perspective introduced above.

\footnotetext{
5 Palgrave Critical University Studies https://link.springer.com/bookseries/14707
} 
The intention to privatise education, including higher education, on the part of influential right-wing actors, is of long standing. Its execution, however, has been gradual and sometimes indirect. The domain of contextual resources operates over a longer timescale than that of the individual psychobiography, but it is here that attention should be focused if we seek to understand how the experience of working in a university has changed so radically in the past three decades or so. One of the most assiduous analysts of the redistribution of resources in higher education is Andrew McGettigan', who in 2013 summarised the situation thus:

Education is being re-engineered by stealth through a directed process of market construction, each move designed to protect the elite and expose the majority. ... A temporary budgetary measure presented as necessary owing to the state of the nation's finances is, in fact, central to a new vision for a marketplace in undergraduate provision.

(McGettigan, 2013: 185)

Elsewhere, McGettigan (2017) points out that the concept of 'benefit' has also become monetised, so that the more abstract notions of education as an inherent, public good are on the wane, with 'good' becoming redefined in terms of creditworthiness - the amount each individual student should pay, related to what they can expect to earn as a direct result of their investment in their degree. Such marketization requires less direct control of curricula: unpopular and 'unprofitable' courses and subjects will simply wither away.

The most recent piece of legislation, at the time of writing, is the Higher Education and Research Act, which passed on to the statute books in April 2017. This development was summarized by the co-founder of one of several UK groups that have fought against the marketisation of higher education, the Campaign for the Public University, as the conclusion to a process by which 'the only functions that are now recognised for universities - whether by policy makers or senior university leaders - are the development of human capital and the enhancement of economic growth' (Holmwood, 2017).

As the distribution of financial resources has been manipulated in this way, the character of the social setting of the university has inevitably changed too. This is evident not only in the increasingly bureaucratic demands and accountability placed on employees, but also in the material semiotics of campuses and university cities. As student numbers have expanded, their role in local economies has increased, with a concomitant growth in the number of residences and retail outlets, as each student is seen as 'a monetarised and commodified, as much as an educational, persona, representing opportunities for profit' (Chatterton, 2010: 512).

In such a context, the structured relations between the different agents in the institution also undergo inexorable alteration. Again, this has been discussed by numerous academic commentators, eminent among whom is Noam Chomsky, who highlights the link between the 'disciplinary technique' of the debt incurred by contemporary undergraduates and their 'indoctrination' into the role of

${ }^{6}$ For comparable accounts of the situation in the US, see Newfield (2008); (2016) 
compliant citizens. Some resist, but, as was noted by a prominent student activist, "The transient nature of the student body ensures that our time to make a stand is short' (Segalov, 2014). Along with others, Chomsky also points out how increased insecurity for academic employees ensures their compliance with new management practices: 'keeping people hanging on a limb than can be sawed off at any time, so that they'd better shut up, take tiny salaries, and do their work' (Chomsky, 2014: 1). Some degree of insecurity may affect everyone dependent on employment for their income, but it does not apply equally to all (Morgan and Wood, 2017; S. Ryan, Connell, \& Burgess, 2017). So, once again, differentials in the psychobiographies of different social actors become relevant: universities now are a different kind of social setting from what they were when I became an academic, and the options for individuals to make careers within them are also very different.

For the contingent reason that I was born earlier than many of my colleagues, I had, by the time the new managerialism was taking serious hold in the university where I worked from 2005 - 2014, already passed my probation and obtained a more secure employment status than has been possible for those entering the profession more recently. Many of these had as undergraduates incurred debts arising from the fees or loans that were not required in my generation, and they had themselves completed the 'National Student Survey' - another instrument that, quite erroneously, encourages the equation of 'consumer satisfaction' with quality (e.g. Jones-Devitt and Samiei, 2010). The first time I heard candidates for a vacant post declare themselves, in the context of presentations to their prospective colleagues, to be 'fully REF-able', I was quite shocked. My expectation was that 'we', as employees on the receiving end of alienating managerialist practices, are consistently sceptical of these misleading rankings and measurements, and would resist internalising this kind of discourse and applying it to ourselves. Yet I have gradually come to realise how it is that my concept of the academic role could contrast so significantly with that of some of my less established - contingently less privileged - colleagues. In a microcosm of the inter-generational conflict that is stoked by the idea that 'baby boomers' have prospered off the backs of 'millennials', universities as workplaces 'are subject to the stratification of academics, the increase in the division of academic labour, and the weakening of the collegiality and the cohesion of the academic community' (Nikolaidis and Maroudas, 2013: 139), making the sector less able to resist neoliberalisation, and thus contributing to the deterioration of working conditions for the workforce as a whole (Courtois and O'Keefe, 2015). This trend is exacerbated by the weakening of trades unions in several ways: through legislation; through their own failure to adapt to campaigning on issues beyond traditional labour relations; and the perception, particularly among some younger staff, that even membership of a trades union may mark them out for discriminatory treatment by management.

\section{What role for discourse analysts?}

Throughout this paper, I have cited critiques of the ways in which neoliberal policies have succeeded in becoming dominant in the provision of education. Their academic authors tend to value knowledge, evidence and reasoned argument - as I do. Yet this extensive literature, published by practitioners, 
teacher educators and pedagogic researchers, as well as scholars in the wider social sciences ${ }^{7}$, has had negligible impact on the progress of the 'reforms' outlined above. This situation is summarised quite brusquely by Mautner (2005: 112), who describes the 'polemics' of academics who are negatively affected by these reforms as being 'as passionate as they are inconsequential'. As she observes, "[a]rticle after article and book after book critiquing the "McUniversity" ... and "academic capitalism" ... may be published, but the entrepreneurial juggernaut, propelled by its powerful supporters, rolls on'.

So it is unsurprising that critics of the role of discourse in the promotion of neoliberal values have succeeded no better in their efforts to achieve substantive change by exposing the contradictions, euphemisms, obfuscations and other linguistic devices that serve the dominant ideology of individualism, competition, assessment and surveillance. Analyses have been produced of various genres of discourse that circulate within and about universities, mostly focusing on the ways the institutions promote themselves and represent the work done by their staff. More than 20 years ago, Fairclough published analyses of texts such as recruitment advertisements and prospectuses to illuminate 'shifting authority relations and shifts in self-identity' within universities (Fairclough, 1993: 157). Analysts have since highlighted the discourse of marketing and advertising in universities' brochures, mission statements, annual reports, prospectuses, corporate websites and print advertisements (e.g. Morrish and Sauntson, 2013; $\mathrm{Ng}$, 2014; Osman, 2008; Zhang and O'Halloran, 2013). Attention is drawn to specific vocabulary and 'keywords' (e.g. Holborow, 2013; Mautner, 2005), as well as to discursive patterns from perspectives such as appraisal theory, analysis of modality and multimodality, etc. Some attention has also been paid by discourse analysts to the interaction between national and international policy statements and the interpretations and implementation of these at local and institutional levels (e.g. Wodak and Fairclough, 2010). Such contributions, like those in this special issue, have done a service to their readers in identifying how the discursive components of contextual resources contribute to the experiences of participants in universities' practices, yet, as noted above, they have had minimal success in altering the general direction of travel.

\section{Conclusion: opening up / closing down}

Previous sections have reviewed: my personal experiences of working in education; the relevance of neoliberalism to those experiences; the critiques of neoliberal ideologies generated by practitioners and academics; and the disregard of those critiques by decision makers. One theme that emerges from this review of descriptions, explanations and prescriptions is the stark contrast between two perspectives.

\footnotetext{
${ }^{7}$ Critical publications by 'dissatisfied', 'frustrated', 'victimized or ignored' academics who have decided to leave the profession constitute their own subgenre, which has been dubbed 'quit-lit' (Morris, n.d.)
} 
The first of these, as articulated or implied by most of the critics cited here, recognises that the experience of education is inherently challenging, in that it disrupts prejudice and common sense, and so is potentially transformative - of individual people but also of relations between them and even of institutions. Academic study - whether of linguistics, literacy, pedagogy, discourse analysis or social theory - entails engagement with complex concepts, about which there is often no stable consensus. For example, the perspective adopted in this paper is consistent with the realist social theory developed by not only Layder, but also Archer (e.g. 1995), Sayer (2000) and Pawson (1989), among others. My identification with these ideas has placed me at odds with some current trends in discourse analysis, particularly those versions of 'discursive construction' which would seem to deny the existence of any objective reality outside of discourse (for fuller discussion of these issues, see e.g. Sealey, 2007, 2010, 2014; Sealey and Carter, 2001, 2004). My own thinking continues to develop in light of my current research into discursive representations of the non-human. This engagement with the new materialism and the philosophy and sociology of science (e.g. Coole and Frost, 2010; Despret, 2013; Dupré, 2002, 2012; Fox and Alldred, 2015) has expanded but also modified my commitment to realist theory, and my understanding of language and discourse in our multispecies world. As academics we learn to accept that our work is corrigible, that debates within and across our disciplines can be productive, and we try to teach our students that their progress may be indicated by their sense of having arrived at a place of less, rather than greater, certainty about what they think they know.

All of these positions are at serious odds with that strand of the neoliberal project (to simplify a range of complex processes into a single noun phrase) that demands simplicity, predictability and measurability. As many people have pointed out, the idea that market competition will inevitably 'drive up standards' is challenged when the 'goods' 'for sale' are neither tangible nor visible - as is inevitably the case with education. The solution, if you intend to retain your commitment to the neoliberal imperative, is to seek out proxies and persuade those involved, by means of rewards and punishments, that whatever proxies you have selected are both valid and measurable. Time and again in my experience in different roles in the English education context I have witnessed repeated iterations of attempts to specify and set down in writing, in advance, some aspect of knowledge, and/or how it has been attained, by whom and to what degree.

In every case, however detailed the stipulations, they inevitably prove open to interpretation, leading to perverse incentives, and so spawning extensive further consultations, reviews, policies and revised texts - as well as career opportunities for new cohorts of bureaucrats, adjudicators and monitors. Any academic who is familiar with assessment in the education system knows about the 'washback' effect, which leads to 'teaching to the test', and could be seen as a counterpart to pernicious techniques used in private enterprise to maximise profit. Thus, if funding for schools and colleges is dependent on evidence of students' achievements matching stated criteria, may it not be expedient for them to exclude those who will not make the grade? If citation counts of publications are the proxy for significance, and 'impact' is a key criterion for 
success, why not publish something highly controversial that will act as 'clickbait' (e.g. see Roelofs and Gallien, 2017)? If high completion rates in the National Student Survey lead to high positions in league tables, why not find ways to reward students for participating? As soon as examples of such tactics are revealed, new techniques are required to stamp them out and prevent further 'gaming' of the system. All this risks closing down the polyphony, complexity, heterogeneity and unpredictability that are characteristics of the pursuit and acquisition of knowledge. The outcome is never determined, however, as the assorted responses of people with different interests lead to further heterogeneity, unpredictability and new sets of interests.

In conclusion, I should stress that my use of social domains in this paper is as a heuristic, intended as a means of recognising the complex and varied contributors to, on a micro scale, my particular experiences as a teacher and researcher, and, on a more macro scale, significant and lasting shifts in the distribution of power and resources throughout educational provision in contemporary society. I have illustrated how people occupying different roles undergraduate student, 'early career' academic, professor/manager - or equivalent roles at different times, are likely to have different perceptions of their goals and interests, and are constrained and enabled in their pursuit of these in differential ways. I have drawn attention to the paradoxes that attend consistent attempts to impose 'free' market conditions on enterprises that are inherently unsuited to them, so inevitably leading to ever tighter regulation and control, and attempts to close down aspects of human experience that cry out to be opened up. To end on a less pessimistic note, solidarity between students and staff, as demonstrated in the recent strike in UK universities (see, e.g. Bergfeld, 2018), is evidence that those cries continue to be voiced, and that at some times, in some contexts, they are heard.

\section{References}

Apple, M. (1995). The politics of a national curriculum. In P. W. Cookson \& B. L. Schneider (Eds.), Transforming schools (pp. 345-370). London: Taylor \& Francis.

Archer, M. (1995). Realist Social Theory: the morphogenetic approach Cambridge: Cambridge University Press.

Ball, S. J. (1993). Education, Majorism and 'the Curriculum of the Dead'. Curriculum Studies, 1(2), pp. 195-214.

Barton, L., Pollard, A., \& Whitty, G. (1993). Change in teacher education: the case in England. In T. S. Popkewitz (Ed.), Changing Patterns of Power: social regulation and teacher education reform (pp. 303-341). New York: SUNY Press.

Bauer, L., \& Trudgill, P. (Eds.). (1998). Language Myths. London: Penguin.

Beattie, N. (1991). Recent, relevant experience: public control and private response in Britain. European Journal of Education, 26(3), pp. 221-230.

Bergfeld, M. (2018). 'Do you believe in life after work?' The University and College Union strike in Britain. Transfer: European Review of Labour and Research, 24 (2), pp. 233-236.

Brown, M. (1998). Educational researchers in universities: the condition of the workforce. British Educational Research Journal, 24(2), pp. 125-139. 
Carter, R. (1996). Politics and knowledge about language: the LINC project. In R. Hasan \& G. Williams (Eds.), Literacy in Society (pp. 1 - 28). London: Addison Wesley Longman.

Carter, R., Goddard, A., Reah, D., Sanger, K., \& Bowring, M. (1997). Working with Texts. A core book for language analysis London \& New York: Routledge.

Chatterton, P. (2010). The student city: an ongoing story of neoliberalism, gentrification, and commodification. Environment and Planning A, 42(3), pp. 509-514.

Chitty, C. (1989). Towards a New Education System: the victory of the new right? : Psychology Press.

Chitty, C. (2013). New Labour and Secondary Education, 1994-2010: Springer.

Chomsky, N. (2014) Thinking like corporations is harming American universities. Paper presented at the Adjunct Faculty Association of the United Steelworkers, Pittsburgh, Pittsburgh.

Collini, S. (2012). What Are Universities For? London: Penguin.

Coman, J. (2017, 21st August 2017). 'Value for money' can't be the only measure of university. The Guardian. Retrieved from https://www.theguardian.com/commentisfree/2016/aug/20/value-formoney-not-only-measure-of-university

Coole, D., \& Frost, S. (Eds.). (2010). New Materialisms: ontology, agency, and politics.

Courtois, A., \& O'Keefe, T. (2015). Precarity in the ivory cage: neoliberalism and casualisation of work in the Irish higher education sector. Journal for Critical Education Policy Studies, 13(1)

Cox, B. (1995). Cox on the Battle for the English Curriculum Sevenoaks: Hodder and Stoughton.

Deem, R. (1996). The future of educational research in the context of the social sciences: A special case? British Journal of Educational Studies, 44(2), pp. 143-158.

Department for Education and Employment. (1997). Initial Teacher Training Curriculum for Primary English. London

Department for Education and Employment. (1998). Teaching: High status, high standards (Requirements for Courses of Initial Teacher Training) London: DfEE.

Department of Education and Science. (1984). Initial teacher training: Approval of courses. Circular 3/84. London

Despret, V. (2013). From secret agents to interagency. History and Theory, 52(4), pp. 29-44.

Dupré, J. (2002). Humans and Other Animals Oxford: Clarendon Press.

Dupré, J. (2012). Processes of Life Oxford: Oxford University Press.

Ellis, A. (2006). The Training and Development Agency for Schools: a political history of challenges faced by the government in improving teacher training provision in England: 1990-2005.

Fairclough, N. (1993). Critical discourse analysis and the marketization of public discourse: the universities. Discourse \& Society, 4(2), pp. 133-168.

Fox, N. J., \& Alldred, P. (2015). Inside the research-assemblage: new materialism and the micropolitics of social inquiry. Sociological Research Online, 20(2), p 6. 
Furedi, F. (2010). Introduction to the marketisation of higher education and the student as consumer. In M. Molesworth, R. Scullion \& E. Nixon (Eds.), The marketisation of higher education and the Student as consumer (pp. 1 - 8). London: Routledge.

Gamble, A. (1985). Smashing the state: Thatcher's radical crusade. Marxism Today, 29(6), pp. 21 - 26.

Gilroy, P. (1999). Inspecting the inspecting of teacher education in England and Wales. Journal of Education for Teaching: International Research and Pedagogy, 25(3), pp. 215-219.

Goddard, R. (1991). Why LINC matters. English in Education, 25(3), pp. 32 - 39.

Graham, J. (1997). The initial teacher training National Curriculum for primary English 1997. A most unnecessary document. Changing English, 4(2), pp. $241-249$.

Graham, J. (1998). Teaching, learning and the National Literacy Strategy. Changing English, 5(2), pp. 115 - 121.

Griffiths, S. (2015). Education policy: consumerism and competition. In M. Beech \& S. Lee (Eds.), The Conservative-Liberal Coalition: Examining the Cameron-Clegg Government (pp. 36 - 49). London: Palgrave Macmillan.

Halliday, M. (1982). Linguistics in teacher education. In R. Carter (Ed.), Linguistics and the Teacher. London: Routledge and Kegan Paul.

Hazelkorn, E. (2008). Learning to live with league tables and ranking: the experience of institutional leaders. Higher Education Policy, 21(2), pp. 193-215.

Hilton, M. (1998). Raising literacy standards: the true story. English in Education, 32(3), pp. 4 - 16.

Holborow, M. (2013). Applied linguistics in the neoliberal university: ideological keywords and social agency. Applied Linguistics Review, 4(2), pp. 229-257.

Holmwood, J. (2017). Requiem for the Public University. Discover Society. Retrieved 15-09-2017.

Jones-Devitt, S., \& Samiei, C. (2010). From Accrington Stanley to academia? The use of league tables and student surveys to determine 'quality'in higher education. In M. Molesworth, R. Scullion \& E. Nixon (Eds.), The marketisation of higher education and the Student as consumer (pp. 86 100). London: Routledge.

Layder, D. (1997). Modern Social Theory: key debates and new directions London: UCL Press.

Marsh, S. (2017, 2nd September 2017). Suicide is at record level among students at UK universities, study finds. The Guardian. Retrieved from https://www.theguardian.com/education/2017/sep/02/suicide-recordlevel-students-uk-universities-study

Mautner, G. (2005). The entrepreneurial university: a discursive profile of a higher education buzzword. Critical Discourse Studies, 2(2), pp. 95-120.

McGettigan, A. (2013). The Great University Gamble: money, markets and the future of higher education London: Pluto Press.

McGettigan, A. (2017). The Treasury view of higher education: variable human capital investment. In A. Davis (Ed.), The Death of Public Knowledge?: How Free Markets Destroy the General Intellect (pp. 103 - 118). London: Goldsmiths Press. 
Monbiot, G. (2016, 15th April 2016). Neoliberalism - the ideology at the root of all our problems. The Guardian. Retrieved from https://www.theguardian.com/books/2016/apr/15/neoliberalismideology-problem-george-monbiot

Morgan, G., \& Wood, J. (2017). The 'academic career'in the era of flexploitation. In E. Armano, A. Bove \& A. Murgia (Eds.), Mapping Precariousness, Labour Insecurity and Uncertain Livelihoods: Subjectivities and Resistance (pp. online edition, no page numbers). London: Routledge.

Morris, A. (n.d.). The rise of 'Quit Lit': what it is and why it matters. Retrieved Date from https://www.noodle.com/articles/the-rise-of-quit-lit-hereswhat-it-is-and-why-it-matters144.

Morrish, L., \& Sauntson, H. (2013). 'Business-facing motors for economic development': an appraisal analysis of visions and values in the marketised UK university. Critical Discourse Studies, 10(1), pp. 61-80.

Newfield, C. (2008). Unmaking the Public University: the forty-year assault on the middle class Cambridge, Mass.: Harvard University Press.

Newfield, C. (2016). The Great Mistake: how we wrecked public universities and how we can fix them: JHU Press.

$\mathrm{Ng}$, C. J. W. (2014). Semioticizing capitalism in corporate brand enactment: the case of Singapore's corporatized universities. Critical Discourse Studies, 11(2), pp. 139-157.

Nikolaidis, E., \& Maroudas, L. (2013). Institutional changes and the expansion of flexible forms of employment in higher education: the case of Greek universities. Journal for Critical Education Policy Studies (JCEPS), 11(3)

Osman, H. (2008). Re-branding academic institutions with corporate advertising: a genre perspective. Discourse \& Communication, 2(1), pp. 57-77.

Ozga, J., Baxter, J., Clarke, J., Grek, S., \& Lawn, M. (2013). The politics of educational change: governance and school inspection in England and Scotland. Swiss Journal of Sociology, 39(2), pp. 37-55.

Pawson, R. (1989). A Measure for Measures: a manifesto for empirical sociology London: Routledge.

Pring, J. (1996). Just desert. In J. Furlong \& R. Smith (Eds.), The role of higher education in initial teacher training (pp. 8 - 24). London: Routledge.

Quicke, J. (1988). The 'new right' and education. British Journal of Educational Studies, 36(1), pp. 5-20.

Rampton, B. (1995). Politics and change in research in applied linguistics. Applied Linguistics, 16(2), pp. 233-256.

Roelofs, P., \& Gallien, M. (2017). Clickbait and impact: how academia has been hacked. Retrieved from http://blogs.lse.ac.uk/impactofsocialsciences/2017/09/19/clickbaitand-impact-how-academia-has-been-hacked/

Ryan, S., Connell, J., \& Burgess, J. (2017). Casual academics: a new public management paradox. Labour \& Industry: a journal of the social and economic relations of work, pp. 1-17.

Ryan, V. (2017, 12th September 2017). Philip Hammond hints at shaming universities into dropping fees for second-rate courses. The Telegraph. Retrieved from http://www.telegraph.co.uk/news/2017/09/12/philiphammond-hints-atshaming-universities-dropping-fees-second/

Sayer, A. (2000). Realism and Social Science London: Sage. 
Sealey, A. (1994). Language and educational control: the construction of the LINC controversy. In D. Scott (Ed.), Accountability and control in educational settings (pp. 121 - 136). London: Cassell.

Sealey, A. (1996). Learning about Language: issues for primary teachers Buckingham: Open University Press.

Sealey, A. (1999). Theories about Language in the National Literacy Strategy Coventry: Centre for Elementary and Primary Education, University of Warwick.

Sealey, A. (2007). Linguistic ethnography in realist perspective. Journal of Sociolinguistics, $11(5)$, pp. $641-660$.

Sealey, A. (2010). Probabilities and surprises: a realist approach to identifying linguistic and social patterns, with reference to an oral history corpus. Applied Linguistics, 31(2), pp. 215-235.

Sealey, A. (2014). Cats and categories-reply to Teubert. Language and Dialogue, $4(2)$, pp. 299-321.

Sealey, A., \& Carter, B. (2001). Social categories and sociolinguistics: applying a realist approach. International Journal of the Sociology of Language, 152, pp. 1 - 19.

Sealey, A., \& Carter, B. (2004). Applied Linguistics as Social Science London: Continuum.

Segalov, M. (2014, March 19th 2014). Universities should support protest, not suppress it The Guardian. Retrieved from https://www.theguardian.com/commentisfree/2014/mar/19/universiti es-support-protest-suppress

Shore, C. (2008). Audit culture and illiberal governance: universities and the politics of accountability. Anthropological Theory, 8(3), pp. 278-298.

Stubbs, M. (1989). The state of English in the English state. Language and education, 3(4), pp. 235 - 250.

Walford, G. (2014). Academies, free schools and social justice. Research Papers in Education, 29(3), pp. 263-267.

Walker, P. (2015, 24th November 2015). England has highest university tuition fees in industrialised world, survey finds. The Guardian. Retrieved from https://www.theguardian.com/education/2015/nov/24/uk-has-highestundergraduate-tuition-fees-in-industrialised-world-survey-finds

West, A., \& Bailey, E. (2013). The development of the academies programme: 'privatising' school-based education in England 1986-2013. British Journal of Educational Studies, 61(2), pp. 137-159. doi:10.1080/00071005.2013.789480 Retrieved from http://dx.doi.org/10.1080/00071005.2013.789480

Whitty, G. (1989). The New Right and the national curriculum: State control or market forces? Journal of Education Policy, 4(4), pp. 329-341.

Whitty, G., \& Menter, I. (1989). Lessons of Thatcherism: education policy in England and Wales 1979-88. Journal of Law and Society, 16(1), pp. 42-64.

Wodak, R., \& Fairclough, N. (2010). Recontextualizing European higher education policies: the cases of Austria and Romania. Critical Discourse Studies, 7(1), pp. 19-40.

Wyse, D. (2003). The National Literacy Strategy: a critical review of empirical evidence. British Educational Research Journal, 29(6), pp. 903-916. 
Zhang, Y., \& O'Halloran, K. L. (2013). 'Toward a global knowledge enterprise': university websites as portals to the ongoing marketization of higher education. Critical Discourse Studies, 10(4), pp. 468-485. 